\title{
The impact of educational technologies in higher education ${ }^{1}$ \\ El Impacto de las Tecnologías Educativas en la Educación Superior
}

\section{Goretti Cabaleiro-Cerviño and Carolina Vera ${ }^{2 *}$}

Universidad de Navarra, Spain

and Universidad de Las Américas, Chile

\footnotetext{
${ }^{1}$ Received: April 10 ${ }^{\text {th }}$ 2019/ Accepted: March 30 ${ }^{\text {th }} 2020$

2 gcabalei@gmail.com; carov_007@hotmail.com
} 


\section{Abstract}

The formation of human capital is key to countries' social, cultural, and economic development. The current literature review pays considerable attention to the ever-increasing proliferation of technology in the careers of college and school graduates. While the presence of educational technology in higher education offers multiple benefits, its implementation also presents challenges. In that sense, the literature has considered multiple tools for improving learning processes. However, the results of such tools vary and are difficult to measure in terms of quality. In this literature review, we analyze the issues surrounding educational technology in higher education.

Keywords: Educational technology; higher education; information technology; role of the teacher.

\section{Resumen}

La formación de capital humano es clave para el desarrollo social, cultural y económico de los países. Esta revisión de literatura presta una atención considerable a la introducción cada vez mayor de la tecnología en las carreras universitarias y en las escuelas de posgrados. Si bien la presencia de tecnología educativa en la educación superior ofrece múltiples beneficios, su implementación también presenta desafíos. En ese sentido, la literatura ha considerado múltiples herramientas para mejorar los procesos de aprendizaje. Ahora bien, los resultados de estas herramientas varían y son difíciles de medir en términos de calidad. En esta revisión de la literatura, analizamos los problemas que rodean la tecnología educativa en la educación superior.

Palabras clave: Tecnología educativa; educación universitaria; tecnologías de la información; rol del profesor.

\section{Resumo}

A formação de capital humano é fundamental para o desenvolvimento social, cultural e econômico dos países. Esta revisão de literatura presta uma atenção considerável à introdução cada vez maior da tecnologia nas carreiras universitárias e nas escolas de pós-graduações. Embora a presença de tecnologia educativa na educação superior ofereça múltiplos benefícios, sua implementação também apresenta desafios. Nesse sentido, a literatura tem considerado múltiplas ferramentas para melhorar os processos de aprendizagem. Agora bem, os resultados destas ferramentas variam e são difíceis de medir em termos de qualidade. Nesta revisão da literatura, analisamos os problemas que rodeiam a tecnologia educativa na educação superior.

Palavras chave: tecnologia educativa, educação superior, tecnologia da informação, papel do professor, estudantes universitários. 


\section{Introduction}

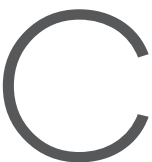

urrently, most countries are paying particular attention to knowledge and information as the essential keys to promoting their productivity, ability to compete, and wealth (Escueta, Quan, Nickow \& Oreoupoulos, 2017). To develop human capital, it is necessary to observe schools and universities to see if they are advancing on a par with the rapidly changing world (Hamidi, Meshkat, Rezaee \& Jafari, 2011). The current literature pays considerable attention to the ever-increasing proliferation of technology in higher education (Ignatyeva, 2015). The consensus seems to be that the global digital agenda highlights the need for a change in educational institutions' pedagogical model to meet the demands of the new 'knowledge society'. Such a change would aim to achieve greater flexibility and to adopt learning technologies to modernize and improve teaching processes and learning in formal contexts (Chais, Ganzer \& Munhoz, 2017).

Information and Communication Technologies (henceforth ICTs) have had a significant impact on the pedagogy of learning in schools and vocational training (Azma, 2011). ICTs include gathering, organizing, and using the information in various forms, including sound, images, and text, through the use of computers or other derivatives of telecommunications (Hamidi et al., 2011). The decrease in the cost of access to technologies and the ease of connecting to the Internet have overcome some of the barriers to the adoption of ICTs by all the actors in education and have opened up new possibilities and areas of interest (Avello \& Duart, 2016). With these facilities, digital technology makes information content easier to find, access, and manage. Each of these steps is central to teaching and learning. Together, they constitute a dynamic digital learning process (Alekseevich \& Borisovna, 2014).

At present, significant transformations have already taken place in the field of higher education. For example, the reorientation of educational patterns, the acquisition of new technologies, and the development of competency-based learning models are helping to strengthen teaching-learning processes and to train key personnel to meet the diverse challenges of the globalized world (López de la Madrid, 2007). In particular, universities have begun to implement ICTs for three main reasons: 1) ICTs represents innovation in learning methods, their presence in the network and the natural adaptation of students; 2) it promotes new goals for the inclusion of technology in education since universities wish to be leaders in the application of new training methods ; and 3) innovation in the ICTs framework encourages the development of new learning paths, such as distance education, more-fluid two-way communication systems, and self-learning (Hamiti, Reka \& Baloghová, 2014). The extensive use of multimedia technology in higher education has changed traditional teaching methods, improving teaching outcomes, and making teaching procedure more active and less passive (Chen \& Xia, 2012). 
However, one key challenge that universities face is the design of educational policies that respond effectively to the requirements and needs of a changing environment. They must review and continuously improve the way they manage ICTs since these technologies are more and more becoming the means for achieving strategic objectives (Aliaga \& Bartolomé, 2005). Within these policies, for example, teachers are required to be flexible and skilled and to respond to diversity and constant social change to ensure high-quality teaching. Higher education must focus on the preparation of people to learn, to become autonomous in their process of accessing and selecting relevant information, and to adapt to changing needs throughout their professional lives (Cobo \& Moravec, 2011). Therefore, despite the motivating power of technologies, the lack of clarity in ICTs strategies and projects in higher education is an urgent challenge that must be addressed (Freitas \& Paredes, 2018).

\section{What is educational technology, and what are its tools?}

The term "educational technology" applied to the university should be understood as a project encompassing the educational process, involving not only the teacher or the structural divisions of the university but also the students and how they apply technology to improve their learning process (Pachler, Cook \& Bachmair, 2010). Educational technologies include information technologies, research technologies for scientific and educational information; technologies for the computer processing of educational information; technologies for organizing the professional training of students; and technologies for the execution and defense of the graduation project or academic works (Ignatyeva, 2015).

The most used tools in this new educational era are multimedia technology, online learning or e-learning, mobile learning or m-learning, blogs, and social networks (Fojtik, 2014). On the one hand, multimedia technology allows the integration of text, numbers, graphics, still or moving images, presentations, a high level of interactivity and, besides, the possibilities of navigating through different documents, which gives students the convenience of understanding words and teaching objects (Chen et al., 2012). It has been shown that multimedia technology has four advantages: 1) it improves information reception and the quality of teaching; 2) it deepens students' memory and their understanding of knowledge through vivid images, videos and refined language, 3) the application of multimedia technology can unite the process of recognition and the affective process; and 4) it can stimulate and motivate study among groups of students and improve the efficiency and the quality of teaching (Ausin, Abella, Delgado \& Hortiguela, 2016). On the issue of improving the quality of teaching, although there is a universal notion that educational technology promotes improvements in learning, these improvements are challenging to measure at present. Thus, an unexplored field is precisely how and to what extent ICTs affect higher education and how these technologies may lead to different careers. 
Also, the intensive use of the Internet and the rise of smart mobile devices have allowed the development of new forms of education, such as online education (e-learning or m-learning), which sometimes complements other modalities, such as classroom sessions, and gives rise to a mixed modality (Avello et al., 2016). E-learning is the teaching-learning process carried out through the Internet, characterized by a physical separation between teachers and students and through which a continuous didactic interaction takes place. In addition, the students become the center of training, having to self-manage their learning with the help of tutors and peers (Avello et al., 2016). Online learning or e-learning is increasingly better evaluated and more widely used in the field of education (Shi, 2016). Although many people show resistance to change and relate it to poor-quality education, studies have shown that it is a mistake to assume that e-learning is of lower quality than face-to-face education (Marín, F., Inciarte, Hérnandez, \& Pitre, 2017). In many developing countries, e-learning is considered a solution to the growing demand for higher education (Ngampornchai \& Adams, 2016); it has already greatly affected the method of learning, and many schools are using it as a pedagogy.

Much of the research emphasizes the possibilities of mobile or online learning because of its portability, flexibility, and context, which favor study and promote collaboration and lifelong learning (Naismith, Lonsdale, Vavoula \& Sharples, 2004). A newer and more portable version of online learning is mobile or m-learning level, named for the portable devices that are sometimes small enough to fit in a pocket or the palm of one's hand. Mobile learning is an emerging field of educational practice in schools, colleges, and universities, as well as in the labor market (Fojtik, 2014). The increasing use of these devices allows us to use multimedia materials, interact, draw diagrams, take notes, complete tasks, watch video conferences, among others (Pachler et al., 2010). This learning technology allows the creation of a developmental continuum that is very effective in the learning process (Osorio \& Duart, 2011).

A blog, according to Doctorow, Dornfest, Johnson, Powers, Trott \& Trott (2002), is a simple web page consisting of brief paragraphs of opinion, information, personal diary entries, or links, called publications, arranged chronologically with the most recent first, in the style of an online diary. Nowadays, blogs are a useful tool to make participating students more active in the learning process. Chawinga (2017) concluded that, within the structure of a blog, students could demonstrate their capacity for critical thinking, take creative risks, and make sophisticated use of language and design elements. Therefore, by doing so continuously, students acquire creative, critical, communicative, and collaborative skills that can be useful for them in academic and professional contexts. Chais et al. (2017) used blogs to teach English as a foreign language in a Brazilian university. He investigated students' perception of blogs as learning tools and found that blogs helped them to improve their writing skills in English by accessing tutorials in the form of podcasts and videos shared by their blogs. 
On the other hand, social networks are structures that promote communication with other people or with institutions through the Internet. Although social networking technologies such as Twitter, Facebook, YouTube, and Instagram, among others, can be a distraction, they can also be an outlet for instructors and students to participate more actively and dynamically and to participate more dynamically and actively in educational activities (Fojtik, 2014). Social networks facilitate fluid communication between students and teachers, allow research, and find resources needed to complete daily tasks more efficiently and to learn almost without realizing it (Pachler et al., 2010). Besides, social networks such as Facebook allow the creation of private groups for each class or each subject, which facilitate the students' ability to solve problems and discover answers through the networks (Osorio et al., 2011).

\section{Skills required by the student to make use of technological education}

There is a broad consensus that students can facilitate their learning process with the help of technology without limitations of time and place because, in such a setting, they can easily collect and analyze data, test hypotheses, design experiments, and conclude (Mahini, Forushan \& Haghani, 2012). However, although many universities recognize the need to innovate along these lines, there is no decisive leadership for students to follow in order to address the required changes themselves (Casas \& Stojanovic, 2013). In higher education, it is essential to emphasize that there are pure or exact science careers that have already been adapted to today's technology. However, some careers have not fully incorporated ICTs and taken advantage of all its benefits (López de la Madrid, 2007). Undoubtedly, students in contact with ICTs obtain the benefits of access to information, more-fluent communication, and the advances in training. However, this requires educational actions related to the use, selection, and organization of information, so that the student is trained to become a mature citizen of the information society (Salinas, 2004).

Pedagogical and digital literacy in ICTs is related to practices of didactically processing and organizing these resources, as well as giving them sense and cultural meaning, a subject that, in a school context, is related to the curriculum as a cultural project for new generations (Sandoval, Rodríguez \& Maldonado, 2017). As such, it is necessary to train teachers digitally and to promote autonomous work by students for the use of diverse educational technology applications (Shi, 2016). Students have some natural abilities for digital reading, navigating, and evaluating what they read to discriminate pages and query strategies (Akcay, 2010). Promoting autonomous work by students has a significant impact on university students' learning through technology (Lai, Wang \& Lei, 2012). Undoubtedly, training in digital skills should be part of the curriculum; however, this is a complex issue because many educational 
institutions have not yet made it a priority to promote skills such as a proactive attitude or self-motivation in their students for the use of online learning resources (Salinas, 2004).

\section{Benefits of Technological Education}

Education is one of the best means through which one can obtain a sense of unity between students and professors in the classroom, as well as build confidence and independence within the students (Salinas, 2004). Educational technology has also proven to play an essential role in achieving these traits and has become the source of fundamental changes in the classroom. The use of technology in education has allowed students to access information outside of classrooms, and this has caused an increase in self-motivation for learning. For example, Azma (2011) found that educational technology helps students significantly improve their scores by expanding the information they can access and, as a result, to broaden their learning environment (Personal Learning Environment). Also, the use of technology has also made education more dynamic and exciting. In particular, studies have shown that tweets are considered a more interactive form of learning compared to traditional knowledge-transfer tools such as lectures (Menkhoff, Chay, Bengtsson, Woodard \& Gan, 2015). Technology has also allowed the development of collaborative learning and greater participation by students. Collaborative learning implies a greater involvement of the classroom community in the learning on a specific topic (Shi, 2016). For example, Wheeler (2010) showed that social networks help students to create a positive contextual training space concerning pedagogical objectives and to get involved in collaborative learning. Such networks motivate students to interact through posting comments or questions on blogs or by "tweeting" on relevant topics.

Online education offers new possibilities for open and flexible learning (Salinas, 2004), which can promote new hybrid models of teaching practices, with teaching methods that require new types of learning experiences. According to Floridi (2014), among the tools that provide greater communication-as well as combine education with ICTs in a specialized manner-are learning analysis or artificial intelligence, adaptive learning, calibrated peer review and scoring automated tests (Balfour, 2013). These are advanced processes that, if they are functional interfaces, can allow teachers to concentrate on human attributes such as caring, creativity, and participation in problem-solving. Finally, the use of technology in education has also helped reduce administrative expenses (Ilgaz, 2015). In particular, the possibilities that the Internet offers are extensive. Thanks to the ease of sharing content, it is possible to use the network to provide students with eBooks and interactive tools to carry out their activities and exercises. Without the need for paper books, the cost of books and other learning materials, as well as administrative costs, can be reduced (Nieto \& Diaz, 2005). Through educational technology, the students' cognitive comprehension has 
been improved, and a significant increase in their performance has been observed; indeed, the speed and quality of learning in schools have improved, as well (Chen et al., 2012).

\section{Role of the teacher in this technological age}

Teaching methods have changed in recent years. In most of the world, the most effective leap forward has been the application of ICTs in higher education since 1990 (Hamidi et al., 2011). Given that technology-based training is a learner-centered method (instead of relying on the teacher), there have been fundamental changes in the learning process, as well as in the roles and responsibilities of the teacher, because the use of tools and technologies reduces some of the limitations of the classroom (Mahini et al., 2012). There is an essential emphasis on teachers today, as they must prepare to provide learning opportunities in addition to technology for students. In fact, preparation to apply technology and technological awareness to improve the quality of student learning must be one of the necessary skills of a teacher (Hamidi et al., 2011).

The teacher is the actor whose central role is to help students access and develop their technological capabilities. The teacher should have the necessary expertise, knowledge, and ability to manage learning activities. With these skills, he or she must try to change the classroom from a static to a dynamic learning environment so that students can communicate with others, both in their classes and in virtual classes around the world (Salinas, 2004). The literature has observed that the main activities of teacher training in e-learning can be divided into two main tasks: 1) planning and delivering content to students, and 2) promoting excellent communication between teachers and students. In this type of training, learning skills strengthen motivation, and students' participation in the learning process is more prominent (Mahini et al., 2012). In the e-learning environment, students can already perform several of the teacher's duties until they are shared, and the quality of education is increased through process efficiency. These changes also mean that the teacher is no longer the only source of knowledge (Mahini et al., 2012). Therefore, teachers in higher education can have a positive impact by learning to apply ICTs optimally and to teach their students to do the same.

\section{Challenges of this technological era}

The implementation of technology in each vocational school and university must be designed and regulated according to the purposes and goals of each institution since one of the most significant challenges is the lack of clarity in planning and 
implementing it. Such planning should be focused on generating motivation for the use of technologies through strategies that allow virtual classrooms to be an alternative learning space (Freitas et al., 2018). The challenges currently facing education imply the incorporation of new pedagogical technologies in a more open and flexible formal education, as several authors have recently pointed out (Castañeda \& Adell, 2013).

On the other hand, vocational schools today do not require instructors to be trained in technology. Because of this, teachers that are not trained in technological applications have a competitive disadvantage in the labor market versus teachers who do have experience with the use of technology. A teacher without such training is an intermediate staff member not qualified for the labor market (Dahil, Karabulut \& Mutlu, 2015). That is, most teachers do not have the level of knowledge or the teaching experience necessary for an adequate education process (Mendoza, Baldiris \& Fabregat, 2015). The instructors, who will be implementers of the technological integration, are severely hampered in using the technology because these instruments are sophisticated, and instructors do not have enough academic equipment. (Dahil et al., 2015). In other words, future teachers must learn in an applied way about the use of technology and extend it with pedagogical practices throughout their training for their professional development.

Similarly, universities face obstacles related to infrastructure, thus limiting students' access to computers (Ngampornchai et al., 2016). Among the challenges, for example, investments are insufficient since investment in technology requires a long-term and high-cost infrastructure. Institutions initially require a stable supply of energy and infrastructure, which is an essential ingredient for implementing stable ICTs systems. The lack of supply is a major obstacle to facilitating operations and Internet access (Hamidi et al., 2011). Many technical institutes and universities teach theoretical education instead of practical training since they do not have enough equipment or technological infrastructure (Dahil et al., 2015).

Another challenge is students' and teachers' view of ICTs as instruments of the configuration of learning and work environments (Nieto et al., 2005). The low acceptance of e-learning is due to the low level of knowledge, a deficient level of computer literacy, an unreliable platform in Internet services, and the high cost of implementation (Folorunso, Ogunseye, \& Sharma, 2006). For example, García-Pérez, Santos-Delgado \& Buzón-García (2016) found that only ten percent of the teachers in his sample reached a high level of technological adaptation, and, for this reason, we believe that the appropriate training should be included in teachers' study plans. Critical success factors of e-learning experts (professors, ICTS experts, and researchers) were explored in developing countries. The four main factors that emerged from the data were classified by ICTs experts: computer training, perceived utility; attitude towards e-learning; and computer self-efficacy. Among students, these four factors are vital for the optimal use of ICTs (Bhuasiri, Xaymoungkhoun, Zo, Rho \& Ciganek, 2012). 


\section{Conclusions}

Educational technology through ICTs has been successfully incorporated in primary and secondary schools (Martínez Sánchez, 2007). However, at the university level, there are continuing challenges regarding the guidelines that should be followed to implement the application of ICTs in all careers (Salinas, 2004). We have observed all the benefits and adversities that universities face when promoting the increase of technological resources in the classroom.

However, it is essential to point out that, although it is generally agreed that the application of educational technology improves educational quality, this cannot be easily proven. If the faculty does not have the proper preparation or creativity to use ICTs, the quality of teaching could be substandard and could affect the learning process. This would be the main challenge since students generally have experience with ICTs and do not need to be trained (Avello et al., 2016). In addition, there are no mechanisms for evaluating quality improvements that come from the application of technology in the classroom. Finally, the application of educational technology varies from career to career because there are many careers, such as the pure sciences or engineering, that require a continuous process of improvement at the technological level. However, several careers that are labeled "theoretical" do not use ICTs as much, although potential positive effects could be found in the use of ICTs, such as participation in MOOCs or blogs, which allow for more global learning and a broader perspective on their careers (Pachler et al., 2010). 


\section{References}

Akcay, A. \& Arslan, A. (2010). The using of blogs in Turkish education. Procedia Social and Behavioral Sciences, 2 (2), 1195-1199. Doi: 10.1016/j.sbspro.2010.03.171

Alekseevich, S.A. \& Borisovna, V. E. (2014). Role of psychological factors in new technology of design engineer education. Procedia - Social and Behavioral Sciences, 128 (April), 469-474. Doi: 10.1016/j.sbspro.2014.03.190

Aliaga, F. \& Bartolomé, A. (2005). The impact of new technologies in education. Paper Presented at the XII National Congress of Educational Research Models, La Laguna, Spain. Retrieved from https://www.uv.es/aliaga/curriculum/Aliaga\&Bartolome2005-borrador.pdf

Ausin, V., Abella, V., Delgado, V. \& Hortiguela, D. (2016). Project-Based Learning through ICT. An Experience of Teaching Innovation from the University Classrooms. Formación Universitaria, 9(3). http://dx.doi.org/10.4067/S071850062016000300005

Avello, R. \& Duart, J. (2016). New collaborative learning trends in e-learning. Keys for the effective implementation. Estudios Pedagógicos, 42 (1), 271-282. Doi: 10.4067/ S0718-07052016000100017

Azma, F. (2011). The Quality Indicators of Information Technology in Higher Education. Procedia - Social and Behavioral Sciences, 30, 2535-2537. http://dx.doi. org/10.4067/S0718-07052016000100017

Balfour, S.P. (2013). Assessing Writing in MOOCs: Automated Essay Scoring and Calibrated Peer Review. Research \& Practice in Assessment, 8, 40-48. Retrieved from https://www.learntechlib.org/p/157940/

Bhuasiri, W., Xaymoungkhoun, O., Zo, H., Rho, J., Ciganek, A. (2012). Critical success factors for e-learning in developing countries: A comparative analysis between ICT experts and faculty, Computers \& Education, 58 (2), 843-855. https://doi. org/10.1016/j.compedu.2011.10.010

Casas, M. \& Stojanovic, L. (2013). Innovación en la Universidad Iberoamericana. Revista de Universidad y Sociedad del Conocimiento (RUSC), 10 (1), 61-74. https:// doi.org/10.7238/rusc.v10i1.1345

Castañeda, L. \& Adell, J. (2013). Entornos Personales de Aprendizaje: Claves para el ecosistema educativo en red. Alcoy: Marfil, ISBN 9788426816382. Retrieved from https://digitum.um.es/digitum/bitstream/10201/30427/1/ CastanedayAdelllibroPLE.pdf 
Chais, C., Ganzer, P. \& Munhoz, P. (2017). Technology transfer between universities and companies: two cases of Brazilian universities. INMR - Innovation \& Management Review, 15(1), 20-40. Retrieved from http://www.revistas.usp.br/rai/ article/view/147833

Chawinga, W. (2017). Taking social media to a university classroom: teaching and learning using Twitter and blogs. International Journal of Educational Technology in Higher Education, 14 (3). Doi: 10.1186/s41239-017-0041-6

Chen, S. \& Xia, Y. (2012). Research on Application of Multimedia Technology in College Physical Education. International Workshop on Information and Electronics Engineering (IWIEE). Procedia Engineering, 29, 4213-4217. Retrieved from https://cyberleninka.org/article/n/1011507

Cobo, C. \& Moravec, J. (2011). Introducción al aprendizaje invisible: la ^evolución fuera del aula. Reencuentro, 62 (diciembre), 66-81. Retrieved from http://www. redalyc.org/pdf/340/34021066008

Dahil, L., Karabulut, A. \& Mutlu, I. (2015). Reasons and results of nonapplicability of education technology in vocational and technical schools in Turkey. Procedia - Social and Behavioral Sciences, 176, 811-818, https://doi.org/10.1016/j. sbspro.2015.01.544

Doctorow, C., Dornfest, R., Johnson, Scoot J, Powers, S., Trott, B. \& Trott, M. (2002). Essential Blogging: Selecting and Using Weblog Tools. O'Reilly Media, ISBN: 0596003889 , Sep, Retrieved from http://shop.oreilly.com/product/9780596003883. do.

Escueta, M., Quan, V., Nickow, A. \& Oreopoulos, P. (2017). Education Technology: An Evidence-Based Review. National Bureau of Economic Research, Working Paper 23744. Doi: $10.3386 /$ w23744

Floridi, L. (2014). The $4^{\text {th }}$ revolution: How the infosphere is reshaping human reality. Oxford: Oxford University Press. Retrieved from https://www.oii.ox.ac.uk/research/ books/the-fourth-revolution/

Fojtik, R. (2014). Mobile Technologies Education. Procedia - Social and Behavioral Sciences, 143, 342-346. https://doi.org/10.1016/j.sbspro.2014.07.417

Folorunso, O., Ogunseye, S. \& Sharma, S.K. (2006). An exploratory study of the critical factors affecting the acceptability of e-learning in Nigerian universities. Information Management \& Computer Security, 14 (5), 496-505. https://doi.org/10.1108/09685220610717781. 
Freitas, A. \& Paredes, J. (2018). Understanding the faculty perspectives influencing their innovative practices in MOOCs / SPOCs: a case study. International Journal of Educational Technology in Higher Education, 15, 5. https://doi.org/10.1186/ s41239-017-0086-6

García-Pérez, R., Santos-Delgado, J.M. \& Buzón-García, O. (2016). Virtual empathy as digital competence in education 3.0. International Journal of Educational Technology in Higher Education. 13 (30). https://doi.org/10.1186/s41239-016-0029-7

Hamidi, F., Meshkat, M., Rezaee \& M., Jafari, M. (2011). Information Technology in Education. Proceedings Computer Science, 3, 369-373. Doi: 10.1016/j.procs.2010.12.

Hamiti, M., Reka, B. \& Baloghová, A. (2014). Ethical Use of Information Technology in High Education. $5^{\text {th }}$ World Conference on Educational Sciences - WCES 2013. Proceedings - Social and Behavioral Sciences, 116, 4411 - 4415. Doi: 10.1016/j. sbspro.2014.01.957

Ignatyeva, I. (2015). The Trend of Technologization of Modern Education (the Use of Humanitarian Technologies). Worldwide trends in the development of education and academic research. Proceedings - Social and Behavioral Sciences, 214, 606 613. Doi: 10.1016/j.sbspro.2015.11.766

Ilgaz, C. (2015). Communication technologies and education in the information age. Procedia - Social and Behavioral Sciences, 174, 636-640. Doi: 10.1016/j. sbspro.2015.01.594

Lai, C., Wang, Q. \& Lei, J. (2012). What factors predict undergraduate students' use of technology for learning? A case from Hong Kong. Computers \& Education, 59 (2), 569-579. ISSN 0360-1315. https://doi.org/10.1016/j.compedu.2012.03.006.

López de la Madrid, M. (2007). Use of ICT in higher education in Mexico: A case study. Apertura, 7 (7), 63-81. University of Guadalajara, Mexico. Retrieved from http://www.redalyc.org/articulo.oa?id=68800706

Mahini, F., Forushan, Z. \& Haghani, F. (2012). The importance of teacher's role in technology-based education. Procedia - Social and Behavioral Sciences, 46, 1614 1618. Doi: 10.1016/j.sbspro.2012.05.348

Marín, F., Inciarte, A., Hérnandez, H. \& Pitre, R. (2017). Strategies of Higher Education Institutions for the Integration of Information Technology and Communication and Innovation in Teaching Processes. A Study in the District of Barranquilla, Colombia. University Education, 10 (6). http://dx.doi.org/10.4067/S071850062017000600004 . 
Martínez Sánchez, F. (2007). The school integration of new technologies. New technologies applied to education. Madrid: McGrawHill, 22-40. Retrieved from http://revistaenfermeria.imss.gob.mx/editorial/index.php/revista_enfermeria/rt/ printerFriendly/185/302.

Mendoza, R., Baldiris, S. \& Fabregat, R. (2015). Framework to Heritage Education using Emerging Technologies. International Conference on Virtual and Augmented Reality in Education. Proceed Computer Science, 75, 239-249. https:// doi.org/10.1016/j.procs.2015.12.244

Menkhoff, T., Chay, Y., Bengtsson, M., Woodard, J. \& Gan, B. (2015). Incorporating microblogging ("tweeting") in higher education: Lessons learnt in a knowledge management course. Computers in Human Behavior, 51 (B), 1295-1302. https:// doi.org/10.1016/j.chb.2014.11.063.

Naismith, L., Lonsdale, P., Vavoula, G., Sharples, M. (2004). Mobile technologies and learning. Futurelab Literature Review Series, Report No 11, Retrieved from http://www.futurelab.org.uk/resources/publications-reports-articles/literaturereviews/Literature-Review203

Ngampornchai, A. \& Adams, J. (2016). Student's acceptance and readiness for E-learning in Northeastern Thailand. International Journal of Educational Technology in Higher Education, 13, 34. Doi: 10.12691/ajnr-7-1-4

Nieto, L. \& Díaz, M. (2005). The training of university professors for curricular flexibility through virtual strategies. Journal of University and Knowledge Society, 2 (1), May. Retrieved from http://www.redalyc.org/articulo.oa?id=78017141009

Osorio, L., \& Duart, J. (2011). Análisis de la interacción en ambientes híbridos de aprendizaje. Comunicar, XIX (37), 65-72. Retrieved from http://rabida.uhu.es/ dspace/handle/10272/5566

Pachler, N., Cook, J., \& Bachmair, B. (2010). Appropriation of Mobile Cultural Resources for Learning. International Journal of Mobile and Blended Learning (IJMBL), 2(1), 1-21. Doi:10.4018/jmbl.2010010101

Salinas, J. (2004). Teaching innovation and use of ICT in university education RUSC. Universities and Knowledge Society Journal, 1, 1, September-November, 1-16. Doi: 10.7238/rusc.v1i1.228

Sandoval, P., Rodriguez, F. \& Maldonado, A. (2017). Evaluation of digital and pedagogical literacy in ICT, based on the opinions of students in Initial Teacher Training. Educaçao e Pesquisa, São Paulo, 43 (1), 127-143, jan./mar. Doi: 10.1590/ s1517-9702201701154907 
Shi, X. (2016). A Comparative Study of E-learning Platform in Reading and Translating Course for Engineering Students. iJET, 11 (4). Doi: https://online-journals.org/ index.php/i-jet/article/view/5551

Wheeler S. (2010). Open Content, Open Learning 2.0: Using Wikis and Blogs in Higher Education. Changing Cultures in Higher Education, Springer, Berlin, Heidelberg. Doi: 10.1007/978-3-642-03582-1_9

\section{Authors}

*Goretti Cabaleiro-Cerviño is Assistant Professor at Universidad de Navarra, Faculty of Business and Economics, in Pamplona, Spain. Her primary research areas are Technology and Innovation Management and Business Strategy.

ORCID: https://orcid.org/0000-0001-8702-3050

Carolina Vera holds M.A. in Economics with mention in Industrial Organization and Social Policies in Georgetown University, USA (with a double degree at Universidad Alberto Hurtado, CL). She studied a BA in Economics in Catholic University of Bolivia. She currently works in research about education and labor markets. She nurtures a keen interest in several fields: Development Economics, Education and Labor Economics and Applied Econometrics.

ORCID: https://orcid.org/0000-0001-9421-9780.

How to reference this article: Cabaleiro-Cerviño, G., \& Vera, C. (2020). The Impact of Educational Technologies in Higher Education. GIST - Education and Learning Research Journal, 20, 155-169. https://doi.org/10.26817/16925777.711 